\title{
Pulmonary Trunk
}

National Cancer Institute

\section{Source}

National Cancer Institute. Pulmonary Trunk. NCI Thesaurus. Code C116918.

An artery arising from the right ventricle of the heart that bifurcates into the left and right pulmonary arteries. 